\title{
Dietary Bacillus NP5 supplement impacts on growth, nutrient digestibility, immune response, and resistance to Aeromonas hydrophila infection of African catfish, Clarias gariepinus
}

\author{
ACHMAD NOERKHAERIN PUTRA ${ }^{1,2, \vartheta}$, MUSTAHAL ${ }^{1,2}$, MAS BAYU SYAMSUNARNO $^{1}$, DODI HERMAWAN ${ }^{1}$, \\ DEVIA GUSNUR FATIMAH ${ }^{1}$, PRAMODITA BALITA PUTRI $^{1}$, SEVIA $^{1}$, RINA ISNAINI $^{1}$, \\ MUHAMAD HERJAYANTO ${ }^{1}$ \\ ${ }^{1}$ Department of Fisheries, Faculty of Agriculture, Universitas Sultan Ageng Tirtayasa. Jl. Raya Jakarta Km. 04, Pakupatan, Serang 42121, Banten, \\ Indonesia. Tel.: +62-254-280330, Fax.: +62-254-281254, `email: Putra.achmadnp@untirta.ac.id \\ ${ }^{2}$ Indonesia-Center of Excellence for Local Food Innovation, Universitas Sultan Ageng Tirtayasa. Jl. Raya Jakarta Km. 04, Pakupatan, Serang 42121, \\ Banten, Indonesia
}

Manuscript received: 9 October 2020. Revision accepted: 21 December 2020.

\begin{abstract}
Putra AN, Mustahal, Syamsunarno MB, Hermawan D, Fatimah DG, Putri PB, Sevia, Isnaini R, Herjayanto M. 2021. Dietary Bacillus NP5 supplement impacts on growth, nutrient digestibility, immune response, and resistance to Aeromonas hydrophila infection of African Catfish, Clarias gariepinus. Biodiversitas 22: 253-261. This study aims to investigate the effects of Bacillus NP5 supplementation as a probiotic on growth, immune response, and resistance of African catfish to Aeromonas hydrophila infection. Catfish with an initial weight of $6.8 \pm 0.1 \mathrm{~g}$ were fed with different doses of Bacillus NP5 (0\%, 1.1\%, 1.2\% B, 1.3\%, and 1.4\%) with three replications and reared for 60 days. The first 45 days were used to observed growth performance, and the last 15 days were used to perform challenge tests against $A$. hydrophila infection. The results showed that the treatment of $1.2 \%$ Bacillus NP5 results in the highest specific growth rate $\left(2.55 \pm 0.28\right.$ day $\left.^{-1}\right)$ and increased protein and lipid digestibility significantly $(\mathrm{P}<0.05)$. Treatment of $1.1-1.3 \%$ Bacillus NP5 increase amylase and lipase activity that significantly higher than 0\% Bacillus NP5 treatment. Supplementation of Bacillus NP5 significantly increased the leukocyte, phagocytic index, and survival rate in African catfish after A. hydrophila infection. Therefore, the supplementation of $1.2 \%$ Bacillus NP5 in the feed increased the growth, immune response, and African catfish resistance to the infection.
\end{abstract}

Keywords: African catfish, Bacillus NP5, growth, probiotic, response immune

\section{INTRODUCTION}

Indonesia is the second-largest producer of aquaculture products in the world after China, with a total of 9.3 million tons in 2018 (FAO 2020). African catfish (Clarias gariepinus) is one of the common commodities found in its freshwater fishery. According to the Ministry of Marine Affairs and Fisheries (2019), catfish production in Indonesia was the $3^{\text {rd }}$ largest after shrimp and tilapia, with a total production of 19.6 thousand tons in 2017. Catfish farming has been intensively and sustainably carried out to fulfill the increasing demand for fish. Zhang et al. (2018) stated that various negative impacts, such as the emergence of disease attacks, decrease in environmental quality, and retardation of fish growth, are associated with the intensification of aquaculture. Aeromonas hydrophila is an opportunistic gram-negative bacterium. It causes Motile Aeromonas Septicemia (MAS) in fish (Korni and Khalil 2017; Shoemaker et al. 2018), which leads to an increase in mortality rate (Maji et al. 2017; Jung-Schroers et al. 2018; Li et al. 2019a). Over the past few decades, fish farmers have adopted the use of antibiotics, a conventional method to control disease attacks (Lee et al. 2019). However, antibiotics and other chemical compounds lead to the improvement of resistance in pathogenic bacteria (Hoseinifar et al. 2018) and increase chemical residues in water and fish (Lee et al. 2016; Hassani et al. 2019). Therefore, an environmentally friendly approach is needed to overcome the problems in aquaculture intensification to maintain sustainability.

Probiotics are environmentally friendly applications to improve fish health and growth (Carnevali et al. 2017). According to Ramesh et al. (2015), it is a substitute for antibiotics and can suppress pathogens' growth without being detrimental to the host and its environment. Furthermore, Li et al. (2019b) reported that it has been widely applied in aquaculture and used as a substitute for fish and shrimp antibiotics. Previous studies showed that probiotics supplementation in aquaculture results in increasing growth and feed digestibility. Probiotics increase digestive enzyme activity (Enferadi et al. 2018; Valiallahi et al. 2018; Arani et al. 2019), increase immunity against pathogens (Amir et al. 2019; Zhu et al. 2019), and improve the water quality of culture media (Elsabagh et al. 2018; Kewcharoen and Srisapoome 2019).

Bacillus NP5 is a Gram-positive bacteria, oxidation fermentation, and catalase-positive (Putra and Widanarni 2015). Previous studies showed that supplementation of Bacillus NP5 in fish increase growth (Putra et al. 2015; Utami et al. 2015), increase immunity against fish pathogens (Widanarni et al. 2014; Febrianti et al. 2016; Tamamdusturi et al. 2016) and improve water quality 
(Putra et al. 2020a). The addition of $1 \%$ and $1.5 \%$ of Bacillus NP5 results in increasing African catfish' growth performance (Putra et al. 2020b). In this study, a probiotic dose range of $1-1.5 \%$ was used to obtain the correct dose of $B$. NP5 in the diet. Besides, there were still a few data related to the effect of Bacillus NP5 addition to catfish's immune system. Therefore, this study was carried out to investigate Bacillus NP5 probiotics' supplementation on growth performance, immune response, and African catfish resistance to $A$. hydrophila infection.

\section{MATERIALS AND METHODS}

\section{Probiotic and feed preparation}

Bacillus NP5 is a probiotic bacteria originating from the intestine of Oreochromis niloticus (Putra and Widanarni 2015). Bacteria were cultured according to the method by Putra and Romdhonah (2019). Bacillus NP5 was cultured aseptically in $250 \mathrm{~mL}$ of tryptic soy broth (TSB) medium and incubated for 18 hours at room temperature. After incubation, the bacterial culture was centrifuged (HITACHI himac CT6E/CT6EL) at the speed of $1000 \times \mathrm{g}$ for 10 minutes at $4^{\circ} \mathrm{C}$, and the bacterial supernatant was washed and homogenized by adding $100 \mathrm{~mL}$ of phosphate buffer saline (PBS, pH 7.2). Furthermore, serial dilutions with PBS were carried out to obtain a $106 \mathrm{CFU} / \mathrm{mL}$ bacterial density. Bacterial supernatant was stored at $4^{\circ} \mathrm{C}$ before being mixed in the feed.

Commercial catfish feed (781, INDONESIA) was used as a basal diet grounded into flour, sieved with $320 \mu \mathrm{m}$ mesh, and thoroughly mixed with chromium oxide of $0.5 \%$ as the digestibility indicator and $3 \%$ tapioca as a binder. Then, $30 \%$ of warm water was added and printed in a 1-2 $\mathrm{mm}$ feed diameter in a pellet machine. Subsequently, the feed was oven heated at $50^{\circ} \mathrm{C}$ for 24 hours, followed by homogenization of $2 \%$ egg yolk (Putra et al. 2015) and sprayed with Bacillus NP5 supernatant according to the treatment dose. The proximate composition of the experimental diet is presented in Table 1.

Table 1. Proximate composition ( $\mathrm{g} / 100 \mathrm{~g}$ feed) of experimental diet

\begin{tabular}{lc}
\hline Proximate & Value \\
\hline Crude protein (\%) & 33.95 \\
Crude lipid (\%) & 7.73 \\
Crude fiber (\%) & 4.16 \\
Ash (\%) & 9.9 \\
Moisture (\%) & 6.49 \\
Organic matter (\%)* & 83.61 \\
Nitrogen-free extracts** & 37.77 \\
Dry matter (\%) & 93.51 \\
Energy (Kcal g feed $\left.{ }^{-1}\right)^{* * *}$ & 275.863 \\
Size feed (mm) & $1-2$ \\
\hline Note: *Dry weight - ash, **100 - protein-lipid - fiber - ash - \\
moisture, **Digestible energy according to NRC (1993), \\
calculated as protein 118.8 Kcal g feed ${ }^{-1}$; lipid 62.6 Kcal g feed ${ }^{-1}$, \\
and carbohydrate: 94.4 Kcal g feed ${ }^{-1}$
\end{tabular}

\section{Fish rearing and experimental procedure}

A total of 375 African catfish obtained from the Baros Seed Center, Serang, Indonesia, were used in this study. Fish rearing was carried out at the Laboratory of Aquaculture, University of Sultan Ageng Tirtayasa, Indonesia. The initial weight of the catfish was $6.8 \pm 0.1 \mathrm{~g}$ were randomly scattered into the round tank with a diameter of $72 \mathrm{~cm}$ diameter and fish density of 25 fish /tank with a water volume of $40 \mathrm{~L}$. The aerator was placed at the center of the tank at $15 \mathrm{~cm}$ from the bottom. The acclimatization process was carried out for seven days, and the fish was unfed for 24 hours before treatment. Feeding was carried out three times daily, i.e., at 08.00, 12.00, and 17.00 Western Indonesian time zone through a satiation method. Approximately $20 \%$ of the total water volume was changed every three days and $50 \%$ every two weeks. The rearing process was carried out for 60 days, of which the first 45 days were used for growth tests and the remaining 15 days for a challenge test with the injection of the pathogen A. hydrophila.

A completely randomized design with five different levels of Bacillus NP5 probiotic ( $0 \%$ or negative control, $1.1 \%, 1.2 \%, 1.3 \%$, and $1.4 \%$ ) with three replications was used in this study. The in-situ water quality monitoring such as temperature (RESUN, Indonesia) was carried out daily, while $\mathrm{pH}$ (LUTRON 208) and dissolved oxygen (LUTRON DO550) were observed weekly. Ammonia measurements were carried out based on the standard Phenate method (APHA 1998) at the beginning and the end of the rearing period. In the present study, water temperature was in the range of $27.1-28.8^{\circ} \mathrm{C}$, while the $\mathrm{pH}$ value during rearing before and after water change was 5.17-7.23. The dissolved oxygen was $5.17-7.23 \mathrm{mg} \mathrm{L}^{-1}$, while the ammonia value was below $2 \mathrm{mg} \mathrm{L}^{-1}$. The value of water quality showed that it was in the normal range for catfish farming, according to Bhatnagar and Devi (2013).

\section{Growth parameters}

The number and weight of African catfish were measured at the beginning and the 45 days to determine the growth performance, which was calculated based on the equation proposed by Huisman (1987) as follow: (i) Feed intake $(\mathrm{g})=$ the initial weight of feed - final weight of feed. (ii) Specific growth rate $\left(\%\right.$ day $\left.^{-1}\right)=100 \times((\ln$ final weight of catfish $-\ln$ initial weight of catfish $/ 50$ days)). (iii) Feed conversion ratio $=$ Total feed consumption/(final weight of catfish - the initial weight of catfish). (iv) Survival rate (\%) $=100 \times$ (final number of catfish/initial number of catfish)

Collection of feces was carried out 2 hours after feeding by shipon from the 7th day until the treatment was complete. Feces was stored at $-4^{\circ} \mathrm{C}$. Nutrient digestibility was calculated based on the equation proposed by Takeuchi (1988) as follows: (i) Dry matter digestibility $(\%)=100 \times$ ( $1-(\%$ chromium content in the diet $/ \%$ chromium content in the feces $))$. (ii) Protein/lipid digestibility $(\%)=100 \times(1$ - ( $(\%$ chromium content in the diet $/ \%$ chromium content in the feces $) \times(\%$ nutrient content in the feces $/ \%$ nutrient content in the feed))) 
Digestive enzyme activity was determined on day 45 A total of 5 fish from each treatment were randomly selected, and their total intestines (anterior and posterior) were surgically removed and weighed. The intestinal samples were crushed to obtain the substrate. The Bergmeyer et al. (1983) method was used to determine the protease activity with casein as a substrate in $0.05 \mathrm{M}$ phosphate buffer, $\mathrm{pH} 7$, and $5 \mathrm{mmol} / \mathrm{L}$ of tyrosine. Amylase activity was determined using 1\% starch solution as a substrate in $20 \mathrm{mM}$ sodium phosphate buffer, $\mathrm{pH} 6.9$, and $20 \mathrm{mM}$ of sodium phosphate according to the method by Worthington (1993). Lipid enzyme activity was calculated based on the procedure described by Borlongan (1990), using olive oil as a substrate and Tris-HCL as a buffer.

\section{Chemical analysis}

Proximate analysis of feed and fish was carried out using the standard method of AOAC (2005). A total of 5 catfish were randomly selected for analysis with the microKjeldahl method to determine crude protein content. Moisture was estimated with an oven at $105^{\circ} \mathrm{C}$ for 6 hours, while the sample was analyzed through extraction with a Soxhlet to determine crude lipid content. The percentage of ash was determined by combustion at $550{ }^{\circ} \mathrm{C}$ for 24 hours, and crude fiber was estimated by an Automatic analyzer.

\section{Experimental infection}

Aeromonas hydrophila was obtained from the Fish Health Laboratory of IPB University for challenge tests carried out on the $45^{\text {th }}$ day. Before the challenge test, Koch's Postulates were performed to increase the virulence of A. hydrophila. Catfish were reared according to the treatment, and the fish density was uniform (15 individuals/tank). Meanwhile, A. hydrophila were cultured on $200 \mathrm{ml}$ of TSB media for 24 hours and incubated at 29 ${ }^{\circ} \mathrm{C}$. After incubation, the culture was centrifuged at $1000 x$ $g$ for 10 minutes and diluted using PBS (pH: 7.2) to obtain $10^{7} \mathrm{CFU} / \mathrm{mL}$ density. Furthermore, it was injected intramuscularly into catfish as much as $0.1 \mathrm{~mL}$ per fish (Putra and Widanarni 2015).

\section{Hematological and immune response}

Evaluations of the hematological and immune response were carried out on days 0,45 , and 60 . Five fish from each treatment were randomly selected to determine the number of erythrocytes and leukocytes according to the method by Blaxhall and Daisley (1973). Blood was mixed with Hayem's and Turk's solutions until it was homogeneous. Erythrocytes were counted using a Neubauer-type hemocytometer under a microscope with a magnification of 400x. Hematocrit level was calculated using a microhematocrit tube following the method by Anderson and Siwicki (1995) Determination of hemoglobin levels in the blood refers to Sahli's method (Wedemeyer and Yasutake 1977). Phagocytosis index was measured by mixing $20 \mu \mathrm{L}$ of the blood sample with $20 \mu \mathrm{L}$ of $A$. hydrophila suspension as an antigen with a density of $10^{7}$ cells $\mathrm{mL}^{-1}$. The phagocyte cells are counted based on the percentage during the phagocytosis process (Ispir and Dorucu 2005).

\section{Statistical analysis}

Data of growth and immune response were analyzed by Analysis of Variance (ANOVA) in Microsoft Office Professional Plus 2016. Duncan Multiple Range Test (DMRT) analyzed significant differences between treatments with a $95 \%$ confidence interval.

\section{RESULTS AND DISCUSSION}

\section{Nutrient digestibility and digestive enzyme activity of African catfish}

Table 2 showed that the dry matter digestibility in treatment 1.1-1.2\% Bacillus NP5 was significantly higher ( $\mathrm{P}<0.05)$ compared to 0\% Bacillus NP5. However, the dry matter digestibility in the treatment of 1.3-1.4\% Bacillus NP5 was not significantly different compared to the control $(0 \%)(\mathrm{P}>0.05)$. Treatment of $0 \%$ and $1.3 \%$ Bacillus NP5 results in the lowest protein digestibility, while the highest was in $1.2 \%$ Bacillus NP5 (P <0.05) treatment. The lowest lipid digestibility was obtained from $0 \%$ and $1.4 \%$ Bacillus NP5 treatment, and the highest one was in 1.1-1.3\% Bacillus NP5 ( $\mathrm{P}<0.05)$. Furthermore, the highest protease enzyme activity was obtained from $1.2 \%$ Bacillus NP5, significantly different from other treatments $(\mathrm{P}<0.05)$. The highest amylase and lipase enzyme activity were obtained from 1.1-1.3\% Bacillus NP5 treatment.

\section{Growth performance}

The growth performance of catfish was presented in Table 3. The highest specific growth rate was in $1.2 \%$ Bacillus NP5 treatment, which significantly different from other treatments $(\mathrm{P}<0.05)$, while treatments of $0 \%, 1.1 \%$, $1.3 \%$, and $1.4 \%$ Bacillus NP5 were not different. The final weights of 1.1-1.3\% Bacillus NP5 treatments were significantly higher than 0\% Bacillus NP5. However, feed intake and survival rates in all treatments were not significantly different $(\mathrm{P}>0.05)$. Furthermore, the highest feed conversion was obtained from 0\% Bacillus NP5 treatment, which was significantly different from the treatment of 1.1-1.4\% Bacillus NP5 (P <0.05).

\section{Whole-body composition}

The whole-body composition of catfish was presented in Table 4. The highest crude protein was obtained from $1.2 \%$ Bacillus NP5 treatment $(\mathrm{P}<0.05)$. Crude lipids in treatments of 1.2-1.4\% Bacillus NP5 were significantly higher than 0-1.1\% Bacillus NP5 treatment. However, the application of Bacillus NP5 does not have any effect on moisture and ash content $(\mathrm{P}>0.05)$. 
Table 2. Nutrient digestibility and digestive enzyme activity of African catfish with five experimental diets containing the different doses of Bacillus NP5

\begin{tabular}{|c|c|c|c|c|c|c|}
\hline \multirow[b]{2}{*}{$\begin{array}{c}\text { Dietary of } \\
\text { probiotic }\end{array}$} & \multicolumn{6}{|c|}{ Digestibility and digestive enzyme parameters* } \\
\hline & $\begin{array}{c}\text { Dry matter } \\
\text { digestibility }(\%)\end{array}$ & $\begin{array}{c}\text { Protein } \\
\text { digestibility }(\%) \\
\end{array}$ & $\begin{array}{c}\text { Lipid } \\
\text { digestibility }(\%)\end{array}$ & $\begin{array}{l}\text { Protease activity } \\
\text { (U. mg protein }{ }^{-1} \text { ) }\end{array}$ & $\begin{array}{l}\text { Amylase activity } \\
\text { (U. mg protein }{ }^{-1} \text { ) }\end{array}$ & $\begin{array}{l}\text { Lipase activity (U. } \\
\text { mg protein }{ }^{-1} \text { ) }\end{array}$ \\
\hline $0 \%$ B. NP5 & $66.86 \pm 0.97^{\mathrm{a}}$ & $76.06 \pm 1.31^{\mathrm{a}}$ & $56.85 \pm 4.39^{\mathrm{a}}$ & $0.007 \pm 0,00^{\mathrm{a}}$ & $1.40 \pm 0.04^{\mathrm{a}}$ & $0.282 \pm 0.00^{\mathrm{a}}$ \\
\hline & 69.09 & $78.10 \pm$ & $67.75 \pm 0.94^{\mathrm{bc}}$ & $0.014 \pm 0.00^{\mathrm{b}}$ & $2.07 \pm 0.034^{\mathrm{b}}$ & $0.325 \pm 0.016^{\mathrm{bc}}$ \\
\hline $1.2 \%$ B. NP5 & $73.01 \pm 1,27^{\mathrm{c}}$ & $85.52 \pm 1.14^{\mathrm{d}}$ & $70.30 \pm 2.34^{\mathrm{c}}$ & $0.057 \pm 0.00^{\mathrm{d}}$ & $2.38 \pm 0.05^{\mathrm{b}}$ & $0.358 \pm 0.00^{\mathrm{c}}$ \\
\hline $1.3 \%$ B. NP5 & $67.75 \pm 0.94^{\mathrm{ab}}$ & $76.16 \pm 0.47^{\mathrm{ab}}$ & $70.86 \pm 0.45^{\mathrm{c}}$ & $0.037 \pm 0.00^{\mathrm{c}}$ & $2.35 \pm 0.08^{\mathrm{b}}$ & $0.354 \pm 0.03^{\mathrm{c}}$ \\
\hline $1.4 \%$ B. NP5 & $65.78 \pm 0.33^{\mathrm{a}}$ & $77.39 \pm 0.72^{\mathrm{bc}}$ & $62.32 \pm 6.46^{\mathrm{ab}}$ & $0.010 \pm 0.00^{\mathrm{a}}$ & $1.28 \pm 0.26^{\mathrm{a}}$ & $0.308 \pm 0.01^{\mathrm{ab}}$ \\
\hline
\end{tabular}

Note: *mean \pm SD values in the same column with similar superscript letters are not significantly different $(P>0.05)$

Table 3. Growth performance of African catfish with five experimental diets containing the different doses of Bacillus NP5

\begin{tabular}{ccccccc}
\hline $\begin{array}{c}\text { Dietary of } \\
\text { probiotic }\end{array}$ & $\begin{array}{c}\text { Initial weight } \\
\left(\mathbf{g ~ f i s h}^{-\mathbf{1}}\right)\end{array}$ & $\begin{array}{c}\text { Final weight } \\
\left(\mathbf{g ~ f i s h}^{-1}\right)\end{array}$ & $\begin{array}{c}\text { Feed intake } \\
(\mathbf{g})\end{array}$ & $\begin{array}{c}\text { Specific growth rate } \\
\left(\boldsymbol{\%} \text { day }^{-1}\right)\end{array}$ & $\begin{array}{c}\text { Feed conversion } \\
\text { ratio }\end{array}$ & $\begin{array}{c}\text { Survival rate } \\
(\%)\end{array}$ \\
\hline $0 \%$ B. NP5 & $6.77 \pm 0.02$ & $19.53 \pm 1.18^{\mathrm{a}}$ & $321.37 \pm 57.62$ & $2.12 \pm 0.12^{\mathrm{a}}$ & $1.82 \pm 0.07^{\mathrm{c}}$ & $96.00 \pm 0.00$ \\
$1.1 \%$ B. NP5 & $6.74 \pm 0.02$ & $23.78 \pm 2.89^{\mathrm{bc}}$ & $330.37 \pm 26.75$ & $2.16 \pm 0.14^{\mathrm{a}}$ & $1.29 \pm 0.02^{\mathrm{b}}$ & $94.67 \pm 2.30$ \\
$1.2 \%$ B. NP5 & $6.75 \pm 0.01$ & $26.26 \pm 1.14^{\mathrm{c}}$ & $328.33 \pm 9.28$ & $2.55 \pm 0.28^{\mathrm{b}}$ & $1.15 \pm 0.04^{\mathrm{a}}$ & $96.00 \pm 0.00$ \\
$1.3 \%$ B. NP5 & $6.84 \pm 0.26$ & $23.91 \pm 1.34^{\mathrm{bc}}$ & $329.62 \pm 8.85$ & $2.35 \pm 0.10^{\mathrm{ab}}$ & $1.17 \pm 0.02^{\mathrm{a}}$ & $96.00 \pm 4.00$ \\
$1.4 \%$ B. NP5 & $6.99 \pm 0.01$ & $21.98 \pm 1.01^{\mathrm{ab}}$ & $324.93 \pm 28.55$ & $2.34 \pm 0.06^{\mathrm{ab}}$ & $1.28 \pm 0.02^{\mathrm{b}}$ & $97.33 \pm 2.30$ \\
\hline
\end{tabular}

${ }^{*}$ mean \pm SD values in the same column with similar superscript letters are not significantly different $(P>0.05)$

Table 4. Whole-body composition of African catfish with five experimental diets containing different doses of Bacillus NP5

\begin{tabular}{ccccc}
\hline \multirow{2}{*}{ Dietary of probiotic } & \multicolumn{3}{c}{ Body composition* } \\
\cline { 2 - 5 } & Crude protein (\%) & Crude lipid (\%) & Moisture (\%) & Ash (\%) \\
\hline $0 \%$ B. NP5 & $10.35 \pm 0.05^{\mathrm{a}}$ & $5.01 \pm 0.02^{\mathrm{a}}$ & $71.07 \pm 0.46$ & $2.82 \pm 0.05$ \\
$1.1 \%$ B. NP5 & $10.07 \pm 0.03^{\mathrm{a}}$ & $5.11 \pm 0.09^{\mathrm{a}}$ & $71.15 \pm 0.02$ & $2.80 \pm 0.12$ \\
$1.2 \%$ B. NP5 & $13.16 \pm 0.28^{\mathrm{c}}$ & $5.52 \pm 0.10^{\mathrm{b}}$ & $72.66 \pm 0.35$ & $2.86 \pm 0.03$ \\
$1.3 \%$ B. NP5 & $11.52 \pm 0.85^{\mathrm{b}}$ & $5.54 \pm 0.33^{\mathrm{b}}$ & $73.96 \pm 0.40$ & $2.77 \pm 0.06$ \\
$1.4 \%$ B. NP5 & $12.05 \pm 1.12^{\mathrm{bc}}$ & $5.12 \pm 0.10^{\mathrm{b}}$ & $73.36 \pm 0.98$ & $2.87 \pm 0.07$ \\
\hline
\end{tabular}

"mean \pm SD values in the same column with similar superscript letters are not significantly different $(P>0.05)$

\section{Hematological and immune response}

Table 5 showed no significant difference in the values of blood profile and phagocyte index of African catfish on day 0 . The same results were also obtained on day 45 , except for the hematocrit value in the probiotic treatment, which was higher than the control $(\mathrm{P}<0.05)$. At the end of rearing (day 60), the highest hemoglobin value was obtained from 1.2\% Bacillus NP5, which was higher than other treatments $(\mathrm{P}<0.05)$. Erythrocyte value in the treatment of 1.1, 1.2, and 1.4\% Bacillus NP5 was not significantly different, but it significantly higher than the 0\% Bacillus NP5 $(\mathrm{P}<0.05)$ treatment. Probiotic treatment had a higher value of hematocrit than 0\% Bacillus NP5 (P $<0.05)$. Supplementation of 1.1-1.2\% Bacillus NP5 results in higher leukocytes than other treatments $(\mathrm{P}<0.05)$. The highest phagocytes index was obtained from $1.2 \%$ Bacillus NP5 ( $\mathrm{P}<0.05)$. The lowest survival rate was at 0\% Bacillus NP5 treatment in weeks 1 and 2 (Figure 1). The highest survival rate after $A$. hydrophila infection was obtained from $1.2 \%$ Bacillus NP5 treatment, namely $75.46 \%$ and $66.67 \%$ in weeks 1 and 2 , respectively.

\section{Discussion}

Bacteria of the genus Bacillus have long been used as probiotics in aquaculture with numerous beneficial effects on their hosts, such as increasing growth performance, enhancing feed digestibility, the production of exogenous enzymes, enhancing immunity against pathogens, and stimulating microbiota populations to inhibit pathogenic colonization (Kuebutornye et al. 2019; Ring Ø 2020). The high activity of digestive enzymes indicates an increase in the development of the intestine of fish and its ability to digest feed (Darafsh et al. 2019). According to Dawood and Khosio (2016), protease, lipase, and amylase are the main enzymes responsible for feed digestion in the digestive tract of fish. This study showed that Bacillus NP5 supplementation increased protease activity, amylase, and lipase in the intestine of catfish compared to controls, especially at doses of $1.1-1.3 \%$. It increases is due to the production of exoenzyme by probiotics. Sankar et al. (2016) reported that the high activity of digestive enzymes in feed treated with probiotics is due to the exoenzyme production by probiotics and its stimulation to the digestive tract of the host. The results obtained in this research are in 
line with the previous studies by Putra et al. (2015 and $2020 \mathrm{~b})$ that the administration of Bacillus NP5 increases the activity of protease, lipase, and amylase enzymes in the digestive tract of the host. Similar results were found on $L$. vannamei (Zokaeifar et al. 2012; Zokaeifar et al. 2014), Javanese carp (Allameh et al. 2015), and tilapia (Midhun et al. 2019).

The results showed that supplementation of 1.1-1.2\% Bacillus NP5 increased nutrient digestibility compared to 0\% Bacillus NP5. A study by Lin et al. (2004) showed that supplementation of Bacillus spp. increased the digestibility of dry matter and protein in white shrimp. Mohapatra et al. (2012) reported the same results, which showed that dietary probiotics in feed significantly $(\mathrm{P}<0.05)$ enhance dry matter, protein, and lipid digestibility compared to controls on the rearing of juvenile rohu, Labeo rohita. In this study, the supplementation of $1.2 \%$ Bacillus NP5 significantly increased the digestibility of dry matter and protein $(\mathrm{P}$ $<0.05$ ), which were considered to be related to the protease enzyme activity in $1.2 \%$ Bacillus NP5 treatment. Meanwhile, increasing protease enzyme activity in probiotic treatment has been reported in other fish species, such as Litopenaeus vannamei, with the application of LactoBacillus pentosus AS13 (Zheng and Wang 2016) and rainbow trout with $L$. plantarum supplementation (Enferadi et al. 2018).

Table 5. The hematological and immune response of African catfish with five experimental diets containing the different doses of Bacillus NP5

\begin{tabular}{|c|c|c|c|c|c|}
\hline \multirow[b]{2}{*}{ Parameter/day } & \multicolumn{5}{|c|}{ Dietary of probiotic* } \\
\hline & $\begin{array}{c}\text { 0\% Bacillus } \\
\text { NP5 }\end{array}$ & $\begin{array}{c}\text { 1.1\% Bacillus } \\
\text { NP5 }\end{array}$ & $\begin{array}{c}1.2 \% \text { Bacillus } \\
\text { NP5 }\end{array}$ & $\begin{array}{c}\text { 1.3\% Bacillus } \\
\text { NP5 }\end{array}$ & $\begin{array}{c}1.4 \% \text { Bacillus } \\
\text { NP5 }\end{array}$ \\
\hline \multicolumn{6}{|l|}{0 day } \\
\hline Hemoglobin ( $\mathrm{g} \%)$ & $6.20 \pm 0.00$ & $6.23 \pm 0.12$ & $6.24 \pm 0.70^{\mathrm{ab}}$ & $6.21 \pm 0, .9$ & $6.21 \pm 0.69$ \\
\hline Erythrocytes $\left(\mathrm{x} 10^{6}\right.$ cell $\left./ \mathrm{mm}^{3}\right)$ & $2.89 \pm 0.09$ & $2.85 \pm 0.04$ & $2.95 \pm 0.05$ & $2.81 \pm 0.08$ & $2.81 \pm 0.08$ \\
\hline Hematocrit $(\%)$ & $17.88 \pm 0.3$ & $17.60 \pm 0.17$ & $17.96 \pm 0.30$ & $20.17 \pm 2.49$ & $20.17 \pm 2.49$ \\
\hline Leukocytes $\left(\mathrm{x} 10^{4} \mathrm{cell} / \mathrm{mm}^{3}\right)$ & $6.32 \pm 0.02$ & $6.35 \pm 0.06$ & $6.34 \pm 0.03$ & $6.16 \pm 0.36$ & $6.16 \pm 0.36$ \\
\hline Phagocyte index $(\mathrm{g} \%)$ & $40.33 \pm 4.51$ & $40.33 \pm 4.73$ & $40.00 \pm 4.36$ & $40.07 \pm 1.53$ & $40.67 \pm 1.53$ \\
\hline \multicolumn{6}{|l|}{45 days $* *$} \\
\hline Haemoglobin $(\mathrm{g} \%)$ & $7.03 \pm 0.42$ & $6.94 \pm 0.53$ & $7.00 \pm 0.20$ & $7.09 \pm 0.62$ & $6.95 \pm 0.64$ \\
\hline Erythrocytes $\left(\mathrm{x} 10^{6}\right.$ cell $\left./ \mathrm{mm}^{3}\right)$ & $2.16 \pm 0.14$ & $2.60 \pm 0.55$ & $2.70 \pm 0.02$ & $2.38 \pm 0.11$ & $2.66 \pm 0.33$ \\
\hline Hematocrit (\%) & $7.82 \pm 0.64^{\mathrm{a}}$ & $11.27 \pm 0.37^{\mathrm{b}}$ & $11.24 \pm 0.69^{b}$ & $11.36 \pm 1.29^{b}$ & $11.36 \pm 1.16^{\mathrm{b}}$ \\
\hline Leukocytes $\left(\mathrm{x} 10^{4}\right.$ cell $\left./ \mathrm{mm}^{3}\right)$ & $8.74 \pm 0.02$ & $8.63 \pm 0.02$ & $8.95 \pm 0.03$ & $8.49 \pm 0.28$ & $8.86 \pm 0.22$ \\
\hline Phagocyte index (g\%) & $41.67 \pm 4.04$ & $40.67 \pm 4.51$ & $40.67 \pm 7.37$ & $40.00 \pm 3.46$ & $41.33 \pm 4.51$ \\
\hline \multicolumn{6}{|l|}{60 days $^{* * * *}$} \\
\hline Hemoglobin (g\%) & $4.40 \pm 0.40^{\mathrm{a}}$ & $5.60 \pm 0.72^{\mathrm{ab}}$ & $6.00 \pm 0.20^{\mathrm{b}}$ & $5.26 \pm 1.16^{\mathrm{ab}}$ & $5.38 \pm 1.22^{\mathrm{ab}}$ \\
\hline Erythrocytes $\left(\mathrm{x} 10^{6}\right.$ cell $\left./ \mathrm{mm}^{3}\right)$ & $1.25 \pm 0.04^{\mathrm{a}}$ & $1.81 \pm 0.03^{b}$ & $1.45 \pm 0.05^{\mathrm{b}}$ & $1.35 \pm 0.09^{\mathrm{ab}}$ & $1.45 \pm 0.05^{\mathrm{b}}$ \\
\hline Hematocrit (\%) & $7.80 \pm 0.40^{\mathrm{a}}$ & $14.20 \pm 0.25^{\mathrm{b}}$ & $12.56 \pm 0.39^{b}$ & $12.32 \pm 0.30^{\mathrm{b}}$ & $15.40 \pm 5.90^{\mathrm{b}}$ \\
\hline Leukocytes $\left(\times 10^{4} \mathrm{cell} / \mathrm{mm}^{3}\right)$ & $8.49 \pm 0.12^{\mathrm{a}}$ & $9.54 \pm 0.02^{\mathrm{b}}$ & $9.45 \pm 0.03^{\mathrm{b}}$ & $9.53 \pm 0.50^{\mathrm{b}}$ & $9.40 \pm 0.39^{\mathrm{b}}$ \\
\hline Phagocyte index $(\mathrm{g} \%)$ & $51.33 \pm 2.52^{\mathrm{a}}$ & $46.67 \pm 1.53^{\mathrm{a}}$ & $66.00 \pm 3.00^{\mathrm{b}}$ & $62.67 \pm 5.03^{b}$ & $58.67 \pm 4.73^{\mathrm{ab}}$ \\
\hline
\end{tabular}

Note: *mean \pm SD values in the same row with similar superscript letters are not significantly different $(P>0.05)$. **before Aeromonas hydrophila infection, ***after A. hydrophila infection.

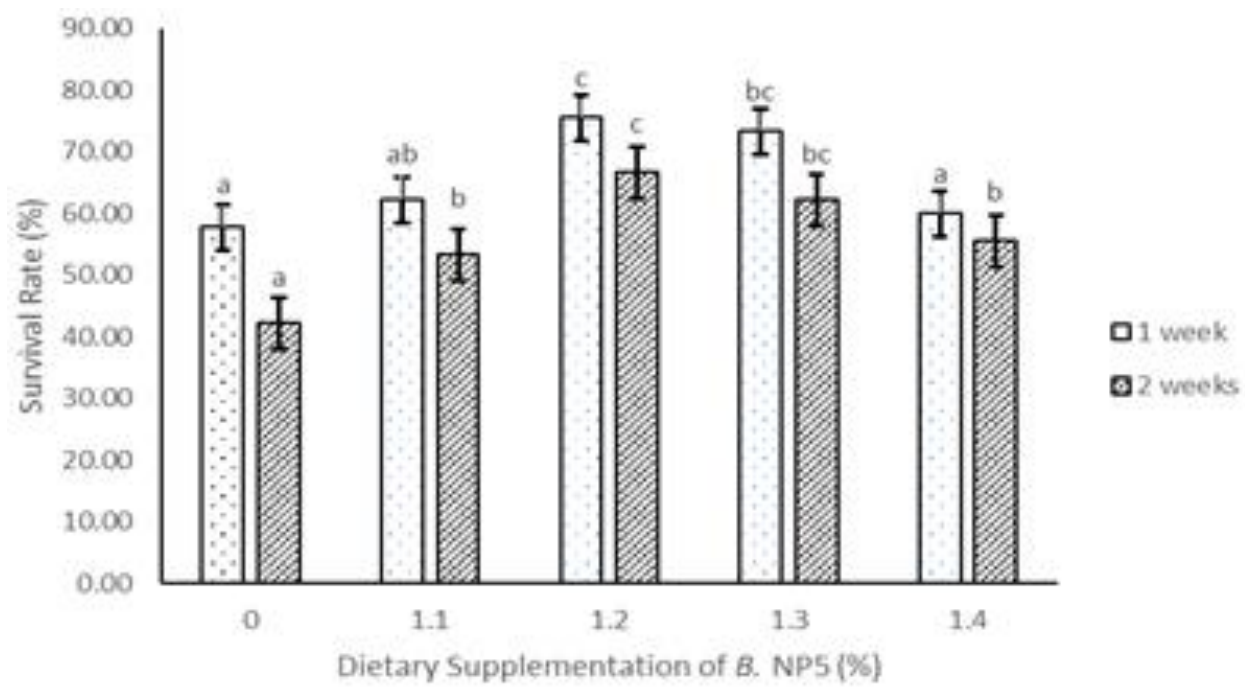

Figure 1. The survival rate of African catfish after Aeromonas hydrophila infection 
The application of probiotics in feed has resulted in the increasing growth of fish and shrimp (Liu et al. 2017; Arani et al. 2019; Xie et al. 2019). Jang et al. (2019) stated that probiotics increase the growth of the host by improving the digestibility of the feed. The highest final weight, specific growth rate, and feed conversion ratio were obtained from $1.2 \%$ Bacillus NP5 treatment $(\mathrm{P}<0.05)$ was considered to be associated with high nutrient digestibility due to increased enzyme activity. According to Wu et al. (2012), probiotic supplementation improves the digestion process of feed and the beneficial microbial population and digestive enzyme activity in the digestive tract of the host. These results were consistent with previous studies, which showed that probiotics have a positive effect on enzyme activity, feed digestibility, and growth performance in hybrid groupers (He et al. 2016), tilapia (Poolsawat et al. 2020), and L. vannamei (Tsai et al. 2019).

The results showed that the feed intake was the same for all treatments, indicating that Bacillus NP5 supplementation in the feed did not affect its palatability (Tantikitti 2014). Similar results were observed in tilapia (Elsabagh et al. 2018), juvenile olive flounder (Lee et al. 2019), and rainbow trout (Nargesi et al. 2019). Supplementation of $1.2-1.4 \%$ Bacillus. NP5 increased crude protein and lipids in the body composition of African catfish. It was consistent with the results obtained in several other species, such as goldfish, by administering $L$. delbrueckii (Zhang et al. 2018) and L. vannamei through the use of B. subtilis and B. licheniformis (Madani et al. 2018). Increasing protein and lipids in the body composition can be caused by the increased digestibility and food absorption of feed. As a result, there were more protein and fat deposits in the body (Abdel-Tawwab et al. 2008; Reda and Selim 2015). The results showed no difference in moisture and ash content in all treatments (P $>0.05)$. Similar results were discovered in L. vannamei (Adel et al. 2017), parrotfish (Liu et al. 2017), and snakehead (Dai et al. 2018).

Several studies have reported that probiotic supplementation reduces the mortality rate of fish and improves its immune system against pathogens (Adel et al. 2017; He et al. 2017; Hassani et al. 2019). Dawood et al. (2016) stated that probiotic supplementations in feed positively affect fish blood profile. This study showed that the erythrocyte and hemoglobin number in African catfish decreased after the challenge test compared to the prechallenge test. Olivier et al. (1981) stated that the decrease in erythrocyte and hemoglobin is related to the ability of pathogens to damage red blood cells. A study by Kumar et al. (2015) showed that the number of erythrocytes and hemoglobin in Catla fingerling after experiencing a challenge test with A. hydrophila bacteria was decreased. The hematocrit number was the ratio of erythrocyte to total blood volume influenced by the number of cells (Soltani et al. 2017). In this study, the hematocrit value obtained by probiotic treatment was higher before and after pathogenic bacterial infection compared to those without probiotics. This result indicates that probiotic has improved the immune system of African catfish. Hematocrit value is related to heath status of fish (Nandi et al. 2017) and administration probiotics stimulated the innate immunity of fish (Adorian et al. 2018). The same results demonstrated by Ahmadifar et al. (2020) who reported the addition of probiotic Pediococcus pentosaceus $10^{8}-10^{9}$ CFU $\mathrm{g}^{-1}$ increased the general hematocrit value compared to the controls in carp. Zhu et al. (2019) also reported that the hematocrit value in tilapia given probiotic $B$. subtilis LT3-1 was increased compared to the controls.

In this study, Bacillus NP5 supplementation in feed significantly increased leukocytes after infection with $A$. hydrophila. These results were in line with the study carried out by Reda and Selim (2015) that supplementation of B. amyloliquefaciens increased the leukocyte of Nile tilapia. A study by Pourgholam et al. (2017) showed that the addition of $L$. plantarum as a probiotic increased the leukocyte number in juvenile Siberian sturgeon. The leukocyte was one of the fish's non-specific defense systems (Uribe et al. 2011). The increase in fish leukocytes was related to the body's defense system response to disease infections (Tanbiyaskur et al. 2015). Phagocytes have been widely used to determine the defense against pathogenic infections (Giri et al. 2012). Tamamdusturi et al. (2016) stated that phagocytosis is the initial cellular immune system after a pathogenic infection was provided by monocytes and granulocytes. According to Djauhari et al. (2016), probiotic supplementation increases the cellular immune system of fish and increasing its resistance to pathogenic infections. The phagocyte index of African catfish increased significantly in the treatment of Bacillus NP5 after the challenge test. This result was similar to the result of a study by Doan et al. (2015) on Pangasius catfish that was challenged with $A$. hydrophila and Zhao et al. (2019) on giant freshwater prawns given $B$. pumilus probiotic.

The increase in blood profile values, especially the leukocytes and phagocyte index in probiotic treatment, indicated an increase in the immune system of African catfish. It was confirmed by increasing the survival rate after the challenge test with A. hydrophila at the Bacillus NP5 treatments. The results showed that Bacillus NP5 supplementation increased African catfish' resistance to $A$. hydrophila infection and increased their survival rate compared to treatment without probiotics. It implies that Bacillus NP5 supplementation increases the cellular and humoral defenses of African catfish. Similar results were also reported by Zokaeifar et al. (2012), with the addition of $B$. subtilis in the feed, which was used to increase the survival rate of $L$. vannamei infected with $V$. harveyi. This is also in accordance with the result in freshwater prawn through the addition of B. licheniformis in the feed (Kumar et al. 2013), Cyprinus carpio with administration $L$. delbrueckii (Zhang et al. 2017), and white shrimp with Pediococcus pentosaceus supplementation in the diet (Adel et al. 2017).

In conclusion, dietary Bacillus NP5 supplement positively increased the growth, immune response, and resistance of African catfish against $A$. hydrophila infection 
with the optimal dose of Bacillus NP5 supplementation in the feed of African catfish was $1.2 \%$.

\section{ACKNOWLEDGEMENTS}

The authors express gratitude to LPPM-UNTIRTA for funding this study through the research internal grant scheme of Penelitian Terapan Internal 2020 (Nomor: B/135/UN.43.9/PT.01.03/2020)

\section{REFERENCES}

Abdel-Tawwab M, Abdel-Rahman AM, Ismael NEM. 2008. Evaluation of commercial live bakers' yeast, Saccharomyces cerevisiae as a growth and immunity promoter for fry Nile tilapia, Oreochromis niloticus (L.) challenged in situ with Aeromonas hydrophila. Aquaculture 280: 185-189. DOI: 10.1016/j.aquaculture.2008.03.055.

Adorian TJ, Jamali H, Farsani HG, Darvishi P, Hasanpour S, Bagheri T, Roozbehfar R. 2018. Effect of probiotic bacteria Bacillus on growth performance, digestive enzyme activity, and hematological parameters of Asian sea bass, Lates calcarifer (Bloch). Probiotics Antimicrob Proteins 11: 248-255. DOI: 10.1007/s12602-018-9393-Z.

Adel M, Yeganeh S, Dawood MAO, Safari R, Radhakrishnan S. 2017. Effects of Pediococcus pentosaceus supplementation on growth performance, intestinal microflora and disease resistance of white shrimp, Litopenaeus vannamei. Aquac Nutr 23 (6): 1401-1409. DOI 10.1111/anu.12515.

Ahmadifar E, Sadegh TH, Dawood MAO, Dadar M, Sheikhzadeh N. 2020. The effects of dietary Pediococcus pentosaceus on growth performance, hemato-immunological parameters and digestive enzyme activities of common carp (Cyprinus carpio). Aquaculture 516: 734656. DOI: 10.1016/j.aquaculture.2019.734656.

Allameh SK, RingØ E, Yusoff FM, Daud HM, Ideris A. 2015. Dietary supplement of Enterococcus faecalis on digestive enzyme activities, short-chain fatty acid production, immune system response and disease resistance of Javanese carp (Puntius gonionotus, Bleeker 1850). Aquac Nutr 23 (2): 331-338. DOI: 10.1111/anu.12397.

Amir I, Zuberi A, Kamran M, Imran M, Murtaza MH. 2019. Evaluation of commercial application of dietary encapsulated probiotic (Geotrichum candidum QAUGC01): Effect on growth and immunological indices of rohu (Labeo rohita, Hamilton 1822) in semi-intensive culture system. Fish Shellfish Immunol 95: 464-472. DOI 10.1016/j.fsi.2019.11.011.

Anderson DP, Siwicki AK. 1995. Basic hematology and serology for fish health program. Proceeding of the Second Symposium on Disease in Asian Aquaculture, October 25-29, 1995.

Association of Official Analytical Chemists (AOAC). 2005. Official Methods of Analysis, $16^{\text {th }}$ ed. AOAC, Arlington, VA, USA.

Arani MM, Salati AP, Safari O, Keyvanshokooh S. 2019. Dietary supplementation effects of Pediococcus acidilactici as probiotic on growth performance, digestive enzyme activities, and immunity response in zebrafish (Danio rerio). Aquac Nutr 25 (4): 854-861. DOI: 10.1111/anu.12904

APHA. 1998. Standard Methods for the Examination of the Water and Wastewater $\left(22^{\text {nd }}\right.$ ed.). American Public Health Association, Washington DC, USA.

Bergmeyer HU, Grossl M, Walter HE. 1983. Reagents for enzymatic analysis. In: Bergmeyer HU (eds.). Methods in Enzymatic Analysis. Verlag Chemie, Weiheim.

Bhatnagar A, Devi P. 2013. Water quality guidelines for the management of pond fish culture. Intl J Environ Sci 3 (6): 1980-2009. DOI: 10.6088/ijes.2013030600019.

Blaxhall PC, Daisley KW. 1973. Routine haematological methods for use with fish blood. J Fish Biol 5 (4): 771-781. DOI: 10.1111/j.10958649.1973.tb04510.x.

Borlongan LG. 1990. Studies on the digestive lipases of milkfish, Chanos chanos. Aquaculture 89 (1-3): 315-325. DOI: 10.1016/00448486(90)90135-A
Carnevali O, Maradonna F, Gioacchini G. 2017. Integrated control of fish metabolism, wellbeing and reproduction: The role of probiotic. Aquac 472: 155-155. DOI: 10.1016/j.aquaculture.2016.03.037.

Dai B, Hou Y, Hou Y, Qian L. 2018. Effects of multienzyme complex and probiotic supplementation on the growth performance, digestive enzyme activity and gut microorganisms composition of snakehead (Channa argus). Aquac Nutr 25 (1): 15-25. DOI: 10.1111/anu.12825.

Darafsh F, Soltani M, Abdolhay HA, Mehrejan MS. 2019. Improvement of growth performance, digestive enzymes and body composition of Persian sturgeon (Acipenser persicus) following feeding on probiotic: Bacillus licheniformis, Bacillus subtilis and Saccharomyces cerevisiae. Aquac Res 51 (3): 957-964. DOI: 10.1111/are.14440.

Dawood MAO, Koshio S, Ishikawa M, El-Sabagh M, Esteban AA, Zaineldin AI. 2016. Probiotics as an environment-friendly approach to enhance red rea bream, Pagrus major growth, immune response and oxidative status. Fish Shellfish Immunol 57: 170-178. DOI: 10.1016/j.fsi.2016.08.038

Dawood MAO, Koshio S. 2016. Recent advances in the role probiotics and prebiotics in carp aquaculture: A review. Aquac 454: 243-251. DOI: $10.1016 /$ j.aquaculture.2015.12.03

Djauhari R, Widanarni, Sukenda, Suprayudi MA, Zairin Jr. M. 2016. Characterization of Bacillus sp. NP and its application as probiotic for common carp (Cyprinus carpio). Res J Microbiol 11 (4-5): 101-111. DOI: $10.3923 / j m .2016 .101 .111$

Doan HV, Doolgindachbaporn S, Suksri A. 2015. Effect of LactoBacillus plantarum and Jerusalem artichoke (Helianthus tuberosus) on growth performance, immunity and disease resistance of pangasius catfish (Pangasius bocourti, Sauvage 1880). Aquac Nutr 22 (2): 444-456. DOI: 10.1111/anu.12263

Elsabagh M, Mohamed R, Moustafa EM, Hamza A, Farrag F, Decamp O, Dawood MAO, Eltholth, M. 2018. Assessing the impact Bacillus strains mixture probiotic on water quality, growth performance, blood profile and intestinal morphology of Nile-Tilapia, Oreochromis niloticus. Aquac Nutr 24 (6): 1613-1622. DOI: 10.1111/anu.12797.

Enferadi MHN, Mohammadizadeh F, Soltani M, Bahri AH, Sheikhzadeh N. 2018. Effects of LactoBacillus plantarum on growth performance, proteolytic enzymes activity and intestine morphology in rainbow trout (Oncorhynchus mykiss). Turkish J Fisheries Aquat Sci 18: 351356. DOI: 10.4194/1303-2712-v18_2_14.

Febrianti D, Yuhana M, Widanarni. 2016. Dietary symbiotic microcapsule influences the immune responses, growth performance and microbial population to white spot syndrome virus in pacific white shrimp (Litopenaeus vannamei). J Fisheries Aquat Sci 11: 28-42. DOI: 10.3923/jfas.2016.28.42.

Food and Agriculture Organization of the United Nations (FAO). 2020. The state of world fisheries and aquaculture 2020. Sustainability in Action. Roma, Italia. DOI: 10.4060/ca9229en.

Giri SS, Sen SS, Sukumaran V. 2012. Effects of dietary supplementation of potential probiotic Pseudomonas aeruginosa VSG-2 on the innate immunity and disease resistance of tropical freshwater fish, Labeo rohita. Fish Shellfish Immunol 32 (6): 1135-1140. DOI: 10.1016/j.fsi.2012.03.019

Hassani MHS, Jourdehi AY, Zelti AH, Masouleh AS, Lakani FB. 2019. Effects of commercial superzist probiotic on growth performance and hematological and immune indices in fingerlings Acipenser baerii. Aquac Intl 28: 377-387. DOI: 10.1007/s10499-019-00468-1.

He R-P, Feng J, Tian X-L, Dong S-L, Wen B. 2017. Effects of dietary supplementation of probiotics on the growth, activities of digestive and non-specific immune enzymes in hybrid grouper (Epinephelus

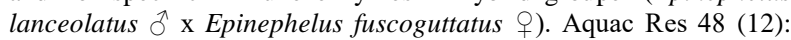
5782-5790. DOI: 10.1111/are.13401.

Hoseinifar SH, Sun Y-Z, Wang A, Zhou Z. 2018. Probiotic as means of diseases control in aquaculture, a review of current knowledge and future perspectives. Front Microbiol 9: 2429. DOI: 10.3389/fmicb.2018.02429.

Huisman EA. 1987. Principles of Fish Production. Department of Fish Culture and Fisheries, Wageningen Agriculture University, Wageningen, Netherland.

Ispir U, Dorucu M. 2005. A study on the effects of levamisole on immune system of Rainbow trout (Oncorhynchus mykiss, Walbaum). Turkish J Vet Anim Sci 29: 1169-1176.

Jang WJ, Lee JM, Hasan TM, Lee B-J, Lim SG, Kong I-S. 2019. Effects of probiotic supplementation of a plant-based protein diet on intestinal microbial diversity, digestive enzyme activity, intestinal structure, and immunity in olive flounder (Paralichthys olivaceus). Fish Shellfish Immunol 92: 719-727. DOI: 10.1016/j.fsi.2019.06.056. 
Jung-Schroers V, Adamek M, Harris S, Syakuri H, Jung A, Irnazarow I, Steinhagen D. 2018. Response of the intestinal mucosal barrier of carp (Cyprinus carpio) to a bacterial challenge by Aeromonas hydrophila intubation after feeding with $\beta-1,3 / 1,6$-glucan. J Fish Dis 41 (7): 1077-1092. DOI: 10.1111/jfd.12799.

Kewcharoen W, Srisapoome P. 2019. Probiotic effects of Bacillus spp. from Pacific white shrimp (Litopenaeus vannamei) on water quality and shrimp growth, immune responses and resistance to Vibrio parahaemolyticus (AHPND strains). Fish Shellfish Immunol 94: 175189. DOI: 10.1016/j.fsi.2019.09.013.

Korni FMM, Khalil F. 2017. Effect of ginger and ist nanoparticles on growth performance, cognition capability, immunity and prevention of motile Aeromonas septicemia in Cyprinus carpio fingerlings. Aquac Nutr 23 (6): 1492-1499. DOI: 10.1111/anu.12526.

Kuebutornye FKA, Abarike ED, Lu Y. 2019. A review on the application of Bacillus as probiotic in aquaculture. Fish Shellfish Immunol 87: 820-828. DOI: 10.1016/j.fsi.2019.02.010.

Kumar NR, Raman RP, Jadhao SJ, Brahmchari RK, Kumar K, Dash G. 2013. Effect of dietary supplementation of Bacillus licheniformis on gut microbiota, growth and immune response in giant freshwater prawn, Macrobrachium rosenbergii (de Man, 1879). Aquac Intl 21: 387-403. DOI: 10.1007/s10499-012-9567-8.

Kumar R, Mukherjee SC, Ranjan R, Vani T, Brahmachari RK, Nayak SK. 2015. Effect of dietary supplementation of Bacillus subtilis on haematological and immunological parameters of Catla catla (Hamilton). Aquac Intl 23: 1275-1292. DOI: 10.1007/s10499-0159883-x.

Lee C, Cha J-H, Kim M-G, Shin J, Woo SH, Kim SH, Kim JW, Ji S-C, Lee K-J. 2019. The effects of dietary Bacillus subtilis on immune response, hematological parameters, growth performance and resistance of juvenile olive flounder (Paralichthys olivaceus) against Streptococcus iniae. J World Aquac Soc 51 (2): 551-562. DOI: 10.1111/jwas. 12680 .

Lee W, Oh JY, Kim E-A, Kang N, Kim K-N Ahn G, Jeon Y-J. 2016. A prebiotic role of Ecklonia cava improves the mortality of Edwardsiella tarda-infected zebrafish via regulating the growth of lactic acid bacteria and pathogen bacteria. Fish Shellfish Immunol 54: 620-628. DOI: 10.1016/j.fsi.2016.05.018.

Li F, Wu D, Gu H-R, Yin M, Ge H-L Liu X-H, Huang J, Zhang Y-G Wang Z-J. 2019a. Aeromonas hydrophila and Aeromonas veroni cause motile Aeromonas septicemia in the cultured Chinese sucker, Myxocyprinus asiaticus. Aquac Res 50 (5): 1515-1526. DOI: 10.1111/are.14028

Li J, Wu Z-B, Zhang Z, Zha J-W, Qu S-Y, Qi Q-Z, Wang G-X, Ling F. 2019b. Effects of potential probiotic Bacillus velezensis $\mathrm{K} 2$ on growth, immunity and resistance to Vibrio harveyi infection of hybrid grouper (Epinephelus lanceolatus $\widehat{\delta} \mathrm{x}$ Epinephelus fuscoguttatus $\$$ ) Fish Shellfish Immunol 93: 1047-1055. DOI: 10.1016/j.fsi.2019.08.047.

Lin HZ, Guo Z, Yang Y, Zheng W, Li ZJ. 2004. Effect of dietary probiotics on apparent digestibility coefficients of nutrients of white shrimp Litopenaeus vannamei Boone. Aquac Res 35 (15): 1441-1447. DOI: $10.1111 / j .1365-2109.2004 .01169 . x$.

Liu C-H, Wu K, Chu T-W, Wu T-M. 2017. Dietary supplementation of probiotic, Bacillus subtilis E20, enhances the growth performance and disease resistance against Vibrio alginolyticus in parrot fish (Oplegnathus fasciatus). Aquac Intl 26 (1): 63-74. DOI: 10.1007/s10499-017-0189-Z

Madani NSH, Adorian TJ, Farsani HG, Hoseinifar SH. 2018. The effects of dietary probiotic Bacilli (Bacillus subtilis and Bacillus licheniformis) on growth performance, feed efficiency, body composition and immune parameters of white leg shrimp (Litopenaeus vannamei) postlarvae. Aquac Res 49 (5): 1926-1933. DOI: 10.1111/are.13648.

Maji UJ, Mohanty S, Pradhan A, Maiti NK. 2017. Immune modulation, disease resistance and growth performance of Indian farmed carp, Labeo rohita (Hamilton), in response to dietary consortium of putative lactic acid bacteria. Aquac Intl 25: 1391-1407. DOI: 10.1007/s10499-017-0122-5.

Ministry of Marine Affairs and Fisheries of the Republic Indonesia. 2019. Kelautan dan Perikanan dalam Angka https://kkp.go.id/setjen/satudata/page/1453-kelautan-dan-perikanandalam-angka. [Indonesian]

Midhun SJ, Arun D, Sahadevan N, Vysakh A, Radhakrishnan EK, Jyothis M. 2019. Administration of probiotic PaeniBacillus polymyxa HGA4C induces morphometric, enzymatic and gene expression changes in Oreochromis niloticus. Aquac 508: 52-59. DOI: 10.1016/j.aquaculture.2019.04.061.

Mohapatra S, Chakraborty T, Prusty AK, Das P, Paniprasad K, Mohanta KN. 2012. Use of different microbial probiotics in the diet of rohu, Labeo rohita fingerling: Effect on growth, nutrient digestibility and retention, digestive enzyme activities and intestinal microflora. Aquac Nutr 18 (1): 1-11. DOI: 10.1111/j.1365-2095.2011.00866.x.

Nandi A, Banerjee G, Dan SK, Ghosh K, Ray AK, 2017. Probiotic efficiency of Bacillus sp. in Labeo rohita challenged by Aeromonas hydrophila: assessment of stress profile, haemato-biochemical parameters and immune responses. Aquac Res 48 (8): 4334-4345. DOI: 10.1111 /are.13255.

National Research Council (NRC). 1993. Nutrient Requirement of Fish. National Academy Press, Washington DC, USA.

Nargesi EA, Falahatkar B, Sajjadi MM. 2019. Dietary supplementation of probiotic and influence on feed efficiency, growth parameters and reproductive performance in female rainbow trout (Oncorhynchus mykiss) broodstock. Aquac Nutr 26 (1): 98-108. DOI: 10.1111/anu.12970.

Olivier G, Lallier R, Lariviere S. 1981. A toxigenic profile of Aeromonas hydrophila and Aeromonas sobria isolated from fish. Canadian J Microbiol 27 (3): 330-333. DOI: 10.1139/m81-050.

Poolsawat L, Li X, He M, Ji D, Leng X. 2019. Clostridium butyricum as probiotic for promoting growth performance, feed utilization gut health and microbiota community of tilapia (Oreochromis niloticus $\times$ O. aureus). Aquac Nutr 26 (3): 657-670. DOI: 10.1111/anu.13025.

Pourgholam MA, Khara H, Safari R, Sadati MAY, Aramli MS. 2017. Influence of Lactobacillus plantarum inclusion in the diet of Siberian sturgeon (Acipenser baerii) on performance and hematological parameters. Turkish J Fisheries Aquat Sci 17: 1-5. DOI: 10.4194/1303-2712-v17_1_01.

Putra AN, Widanarni. 2015. Screening of amylolytic bacteria as candidates of probiotic in tilapia Oreochromis sp. Res J Microbiol 10: 1-13. DOI: 10.3923/jm.2015.1.13.

Putra AN, Widanarni, Utomo NBP. 2015. Growth performance of tilapia (Oreochromis niloticus) fed with probiotic, prebiotic and symbiotic in diet. Pak J Nutr 14: 263-268. DOI: 10.3923/pjn.2015.263.268.

Putra AN, Romdhonah Y. 2019. Effects of dietary Bacillus NP5 and sweet potato extract on growth and digestive enzyme activity of dumbo catfish, Clarias sp.. Jurnal Akuakultur Indonesia 18 (1): 80-88. DOI: 10.19027/jai.18.1.80-88.

Putra AN, Syamsunarno MB, Ningrum W, Jumyanah, Mustahal. 2020a. Effect of the administration of probiotic Bacillus NP5 in the rearing media on water quality, growth, and disease resistance of African catfish (Clarias gariepinus). Biodiversitas 21 (6): 2566-2575. DOI: 10.13057/biodiv/d210629.

Putra AN, Mustahal, Syamsunarno MB. 2020b. Effects of dietary probiotic Bacillus NP5 on the growth performances of catfish $\begin{array}{lllll}\text { (Clarias } & \text { sp.). } & \text { Biotropia } 27 & \text { (1): 51-59. }\end{array}$ 10.11598/btb.2020.27.1.1102.

Ramesh D, Vinothkanna A, Rai AK, Vignesh VS. 2015. Isolation of potential probiotic Bacillus spp. and assessment of their subcellular components to induce immune responses in Labeo rohita against Aeromonas hydrophila. Fish Shellfish Immunol 45: 268-276. DOI: 10.1016/j.fsi.2015.04.018

Reda RM, Selim KM. 2015. Evaluation of Bacillus amyloliquefaciens on the growth performance, intestinal morphology, hematology and body composition of Nile tilapia, Oreochromis niloticus. Aquac Intl 23: 203-217. DOI: 10.1007/s10499-014-9809-z.

RingØ E. 2020. Probiotics in shellfish aquaculture. Aquac Fisheries 5: 1 27. DOI: 10.1016/j.aaf.2019.12.001

Sankar H, Philip B, Philip R, Singh ISB. 2016. Effect of probiotic on digestive enzyme activities and growth of cichlids, Etroplus suratensis (Pearl spot) and Oreochromis mossambicus (Tilapia). Aquac Nutr 23 (4): 852-864. DOI: 10.1111/anu.12452.

Shoemaker CA, Mohammed HH, Bader TJ, Peatman E, Beck BH. 2018. Immersion vaccination with an inactivated virulent Aeromonas hydrophila bacterin protects hybrid catfish (Ictalurus punctatus $\mathrm{X}$ Ictalurus furcatus) from motile Aeromonas septicemia. Fish Shellfish Immunol 82: 239-242. DOI: 10.1016/j.fsi.2018.08.040.

Soltani M, Abdy E, Alishahi M, Mirghaed AT, Hosseini-Shekarabi P. 2017. Growth performance, immune-physiological variables and disease resistance of common carp (Cyprinus carpio) orally subjected to different concentrations of LactoBacillus plantarum. Aquac Intl 25: 1913-1933. DOI: 10.1007/s10499-017-0164-8. 
Takeuchi T. 1988. Laboratory work-chemical evaluation of dietary nutrients. In: Watanabe $\mathrm{T}$ (eds). Fish Nutrition and Mariculture. Kanagawa International Fisheries Training Centre, Japan International Cooperation Agency (JICA), Japan.

Tamamdusturi R, Widanarni, Yuhana M. 2016. Administration of microencapsulated probiotic Bacillus sp. NP5 and prebiotic mannan oligosaccharide for prevention of Aeromonas hydrophila infection on Pangasianodon hypophthalmus. J Fisheries Aquat Sci 11: 67-76. DOI: $10.3923 /$ jfas.2016.67.76.

Tanbiyaskur, Widananrni, Lusiastuti AM. 2015. Administration of Bacillus NP5 and oligosaccharide to enhance the immune response in tilapia Oreochromis niloticus towards streptococcosis. Intl J Sci Basic Appl Res 20 (2): 301-315.

Tantikitti C. 2014. Review article: Feed palatability and the alternative protein sources in shrimp feed. Songklanakarin J Sci Technol 36 (1) 51-55.

Tsai C-Y, Chi C-C, Liu C-H. 2019. The growth and apparent digestibility of white shrimp, Litopenaeus vannamei, are increased with the probiotic, Bacillus subtilis. Aquac Res 50 (5): 1475-1481. DOI: 10.1111/are.14022

Uribe C, Folch H, Enriquez R, Moran. 2011. Innate and adaptive immunity in teleost fish: A review. Veterinarni Medicina 56 (10): 486-503. DOI: 10.17221/3294-VETMED.

Utami DAS, Widanarni, Suprayudi MA. 2015. Quality of dried Bacillus NP5 and its effect on growth performance of tilapia Oreochromis niloticus. Pak J Biol Sci 18: 88-93. DOI: 10.3923/pjbs.2015.88.93.

Valiallahi J, Pouranasali M, Janalizadeh E, Bucio A. 2018. Use of LactoBacillus for improves growth and enhanced biochemical, hematological, and digestive enzyme activity in common carp at Mazandaran, Iran. North Am J Aquac 80 (2): 206-215. DOI 10.1002/naaq.10027.

Wedemeyer GA, Yasutake. 1977. Clinical Methods for the Assessment on the Effect of Environmental Stress on Fish Health. U.S Fish and Wildlife Service, USA

Widanarni, Yuhana M, Muhamad A. 2014. Bacillus NP5 improves growth performance and resistance against infectious myonecrosis virus in white shrimp Litopenaeus vannamei. Ilmu Kelautan 19: 211-218. DOI: 10.14710/ik.ijms.19.4.211-218.

Worthington V. 1993. Worthington Enzyme Manual. Enzymes and Related Biochemicals. Worthington Chemical Corp, USA

Wu ZX, Feng X, Xie LL, Peng XY, Chen XX. 2012. Effect of probiotic Bacillus subtilis $\mathrm{Ch} 9$ for grass carp, Ctenopharyngodon idella (Valenciennes, 1844), on growth performance, digestive enzyme activities and intestinal microflora. J Appl Ichthyol 28 (5): 721-727. DOI: 10.1111/j.1439-0426.2012.01968.x.

Xie J-J, Liu Q-Q, Liao S, Fang H-H, Yin P, Xie S-W, Tian X, Liu Y-J, Niu J. 2019. Effects of dietary mixed probiotics on growth, nonspecific immunity, intestinal morphology and microbiota of juvenile pacific white shrimp, Litopenaeus vannamei. Fish Shellfish Immunol 90: 456-465. DOI: 10.1016/j.fsi.2019.04.301.

Zhang C-N, Zhang J-L, Guan W-C, Zhang X-F, Guan S-H, Zeng Q-H, Cheng G-F, Cui W. 2017. Effects of Lactobacillus delbrueckii on immune response, disease resistance against Aeromonas hydrophila, antioxidant capability and growth performance of Cyprinus carpio Huanghe var. Fish Shellfish Immunol 68: 84-91. DOI: 10.1016/j.fsi.2017.07.012.

Zhang C, Zhang J, Fan W, Huang M, Liu M. 2018. Effects of dietary Lactobacillus delbrueckii on growth performance, body composition, digestive and absorptive capacity, and gene expression of common carp (Cyprinus carpio Huanghe var). Aquac Nutr 25 (1): 166-175. DOI: $10.1111 /$ anu. 12840.

Zhao C, Zhu J, Hu J, Dong X, Sun L, Zhang X, Miao S. 2019. Effects of dietary Bacillus pumilus on growth performance, innate immunity and digestive enzymes of giant freshwater prawns (Macrobrachium rosenbergii). Aquac Nutr 25 (3): 712-720. DOI: 10.1111/anu.12894

Zheng CN, Wang W. 2016. Effects of Lactobacillus pentosus on the growth performance, digestive enzyme and disease resistance of white shrimp, Litopenaeus vannamei (Boone, 1931). Aquac Res 48 (6): 2767-2777. DOI: 10.1111/are.13110.

Zhu C, Yu L, Liu W, Jiang M, He S, Yi G, Wen H, Liang X. 2019. Dietary supplementation with Bacillus subtilis LT3-3 enhances the growth, immunity and disease resistance against Streptococcus agalactiae infection in genetically improved farmed tilapia, Oreochromis niloticus. Aquac Nutr 25 (6): 1241-1249. DOI: 10.1111/anu.12938.

Zokaeifar H, Balcazar JL, Saad CR, Kamarudin MS, Sijam K, Arshad A, Nejat N. 2012. Effect of Bacillus subtilis on the growth performance, digestive enzymes, immune gene expression and disease resistance of white shrimp, Litopenaeus vannamei. Fish Shellfish Immunol 33: 683-689. DOI: 10.1016/j.fsi.2012.05.027.

Zokaeifar H, Babaei N, Saad CR, Kamarudin MS, Sijam K, Balcazar JL. 2014. Administration of Bacillus subtilis strains in the rearing water enhances the water quality, growth performance, immune response, and resistance against Vibrio harveyi infection in juvenile white shrimp, Litopenaeus vannamei. Fish Shellfish Immunol 36 (1): 68-74. DOI: $10.1016 /$ j.fsi.2013.10.007. 